\title{
O tkaniu z cytatów (Elżbieta Biardzka, Przytoczenia w prasie codziennej, Oficyna Wydawnicza Leksem, Lask 2014, ss. 203)
}

Gdy myślę o książce Elżbiety Biardzkiej, przychodzą mi do głowy słowa „Oryginalność echa polega na powtarzaniu”, których autorem jest Włodzimierz Ścisłowski. Właśnie wokół powtarzania, dublowania, reprodukcji osnuta jest monografia wrocławskiej romanistki Przytoczenia w prasie codziennej wydana w 2014 roku przez Oficynę Wydawniczą Leksem w Łasku. Dwa elementy pojawiające się w tytule wymagają wyjaśnienia - o ile podstawową kwestią omawianą w publikacji bardzo szczegółowo jest „przytoczenie”, o tyle „prasa codzienna” nie jest już sformułowaniem tak oczywistym. Wybrany do badań materiał pochodzi z mediów zróżnicowanych na wielu poziomach a ich wspólnym mianownikiem jest stała, krótka amplituda czasowa - są to dzienniki. Ale dzienniki różniące się celami, odbiorcami, punktami widzenia, perspektywami nadawania, systemami oceniania i obrazem świata. A zatem też w najprzeróżniejszy sposób wykorzystujące możliwości języka, w tym także cudzych słów, których potencjał - jak wiadomo - jest ogromny. Źródłem tekstów tworzących korpus materiałowy są w kolejności alfabetycznej: „Dziennik Gazeta Prawna”, „Fakt”, „Gazeta Wyborcza”, „Polska The Times. Gazeta Wrocławska”, „Rzeczpospolita” oraz „Super Ekspress”. Wybór ten nie jest wyjaśniony, wprawdzie Autorka pisze, że sięga po codzienną prasę wysokonakładową, ale przecież tytuły należą do różnych typów prasy (również jeśli chodzi o dziennikarską rzetelność). Do badań wybrano 1300 sekwencji mowy przytoczonej z 35 numerów wymienionych gazet i trzeba przyznać, iż jest to materiał umożliwiający ogląd i dostatecznie szczegółowy, i dający szeroką perspektywę.

Elżbieta Biardzka dała się już poznać, zwłaszcza w środowisku polskich romanistów, jako znakomita znawczyni problematyki związanej z mową 
przytaczaną, a książka Przytoczenia w prasie codziennej w pewnym sensie jest transpozycją ustaleń z jej wcześniejszych prac. Jest ona bowiem autorką kilkunastu artykułów z tego zakresu, a w 2009 roku ukazała się jej rozprawa zatytułowana Les échos $d u$ „,Monde”. Pratiques du discours rapporté dans un journal de la presse écrite. Ten francuskojęzyczny tom stanowi źródło metodologiczne i inspirację badawczą dla omawianej książki (powtarza się w niej niczym echo), tak więc przedstawiona problematyka różni się w zasadzie materiałem badawczym - w pierwszej książce oglądowi poddano materiały prasowe publikowane we francuskim dzienniku „Le Monde”, w recenzowanej rozprawie materiał jest polskojęzyczny, pochodzi z codziennych gazet z 2011 roku. Trzeba jednak zauważyć, że z pozoru błaha różnica tak naprawdę ma kolosalne znaczenie, wiąże się bowiem z rozróżnieniem dwu systemów gramatycznych dwu odrębnych języków, z których do badań wybrano konstrukcje wprowadzające cudzą mową do przekazu.

Elżbieta Biardzka wybiera akurat tę przestrzeń badawczą z kilku powodów: wychodzi poza dość wąski opis podręcznikowy (z reguły obejmujący trzy typy przytoczeń - mowę niezależną, mowę zależną i mowę pozornie zależną), tworząc tym samym pełniejszy rejestr praktyk przytaczania, rozbudowując go o obraz ,teatru słowa zawartego w prasie" zwymiarowany socjolingwistycznie oraz pragmatycznie. Autorka decyduje się na analizę materiału prasowego, gdyż - jak pisze we Wprowadzeniu: ,[...] gazety opowiadają bardzo często o mówieniu (a nie o zdarzeniach niewerbalnych), o wydarzeniach słownych i zawierają ogromną liczbę najróżniejszych relacji «cudzych słów»" [Biardzka 2014: 9].

Szkielet teoretyczny recenzowanej monografii wyrasta z językoznawstwa dyskursu, zwanego też językoznawstwem wypowiadania (to tzw. francuska pragmatyka), które odstępuje od strukturalnej metodologii na rzecz włączania do analiz sytuacji komunikacyjnej i związanych z nią parametrów. Na marginesie trzeba zaznaczyć, że Autorka pokrótce objaśnia, do jakich zjawisk językowych czy komunikacyjnych odsyła nas w tym ujęciu słowo dyskurs, z którym w obrębie polskiej refleksji lingwistycznej mamy sporo zamieszania. Elżbieta Biardzka jest doskonale zorientowana w literaturze przedmiotu, zwłaszcza we francuskich metodologiach opisu przytoczeń. Poza nielicznymi spolszczonymi tekstami (np. Mowa pozornie zależna we wspótczesnym języku francuskim Charles'a Bally'ego pomieszczona w tomie Stylistyka Bally'ego. Wybór tekstów czy Polifoniczna teoria opowiadania Oswalda Ducrota opublikowana w „Pamiętniku Literackim”) Autorka przywołuje liczne prace francuskich klasyków: Bally’ego, Ducrota czy Jacqueline Authier-Revuz. To przybliżenie polskiemu odbiorcy dawnych i współczesnych tekstów badaczy francuskich 
podnosi wartość tej publikacji (zwłaszcza w czasach wielkiej promocji w nauce języka angielskiego ze stratą dla francuszczyzny).

Aparat teoretyczny wyrasta z pojęć: polifonii Ducrota i grupy ScaPoLine, heterogeniczności wypowiadania Authier-Revuz oraz dialogiczności Jacquesa Bresa, z którymi Elżbieta Biardzka nie zawsze się zgadza, ale też czasami podejmuje dyskusję, kwestionując w jakiejś części (np. tezę o rozdwojeniu wypowiadawczym) lub odrzucając (podejście Authier-Revuz do mowy znarratywizowanej). Jako znaczące dla swoich badań uznaje Autorka rozpatrywanie mowy przytoczonej w kontekście metajęzyka (autonimia, znak ikoniczny w mowie niezależnej i parafrazowanie w mowie zależnej). Elżbieta Biardzka zdecydowanie potwierdza rozdzielność mowy niezależnej i zależnej, sprzeciwia się (jak jej mentorka Authier-Revuz) tezie o ich transformacyjnym powinowactwie (mowa zależna nie umożliwia przejścia do mowy niezależnej). Czytamy: „Mowa niezależna i mowa zależna to dwa oddzielne modele przytaczania cudzych słów, a zależą one od wyboru sprawozdawcy, jego pozycji w ramach wypowiadania, mogą ulegać pewnym montażom w dyskursie, ewoluując w kierunku swoistego continuum praktyk związanych z opowiadaniem o mówieniu" [Biardzka 2014: 22].

Podkreślenia wymaga ujęcie poszerzające repertuar możliwości przytaczania, niedające się sprowadzić do wymienienia konstrukcji gramatycznych służących temu celowi. Jest to możliwe, gdyż w rozpatrywaniu przytoczeń kryterium semantyczne zrównuje się z kryterium gramatycznym, co skutkuje licznymi wskazaniami przytoczeń odmiennych od mowy zależnej i niezależnej, znanych od starożytności i często jako jedynych omawianych w podręcznikach pisanych zgodnie z gramatyczną tradycją. Wskazanie wielu typów mowy przytoczonej umożliwiła duża próba tekstowa oraz jasne, sprecyzowane założenia metodologiczne wydzielania przytoczeń do badań. Sekwencja mowy przytoczonej odnosi się do sytuacji komunikacyjnej, która uprzedzała tę, w trakcie której pojawia się przytoczenie, i złożona jest z dwu elementów: mowy towarzyszącej (zwerbalizowanie wybranych przez sprawozdawcę komponentów niewerbalnych uprzedniej sytuacji komunikacyjnej, np. uczestnicy czynni i bierni, czas, przestrzeń, okoliczności towarzyszące) oraz z cytatu (uprzednio wypowiedziane ciągi werbalne). Ten dualizm skutkuje trudnościami z ustaleniem fragmentów tekstu, które po pierwsze przynależą do mowy przytoczonej, a po drugie składają się na mowę towarzyszącą i cytat. Wyjaśnienia Badaczki są na tyle dokładne, niemal instruktażowe, że wątpliwości zostają rozwiane. To warta podkreślenia umiejętność, wcale nieczęsta wśród autorów specjalistów.

W części wstępnej Elżbieta Biardzka opisuje także tryb postępowania analitycznego, które obejmuje trzy etapy: a) delimitację i opis budowy kompletnych 
sekwencji mowy przytoczonej oraz odgraniczenie w niej mowy towarzyszącej i cytatu, b) przedstawienie kombinatoryki w mowie przytoczonej (montowanie jej sekwencji z rozmaitych układów mowy towarzyszącej i cytatu) oraz c) opis funkcji przytoczeń w dyskursie prasowym. Ta etapowość gwarantuje pełny i rzetelny opis poszczególnych elementów mowy przytoczonej obecnej w polskiej prasie codziennej. Na tle doskonale opracowanego wstępu teoretycznego, który Autorka prezentuje przekonująco i z wprawą (bez zamąceń, co godne podkreślenia zwłaszcza w przypadku dualności terminologicznej nomenklatura francuska nie pozostaje bez polskich odpowiedników), najsłabiej wypada rozdział zatytułowany Pakt komunikacyjny prasy pisanej. Gdyby Autorka wytłumaczyła, jak rozumie pojęcie prasy i dlaczego w tytule pojawia się z różnych względów nieoczywiste połączenie „prasa pisana” (czy wobec tego istnieje „prasa mówiona”?), to może wrażenie byłoby inne. Widać, że nie jest to przestrzeń, w której Elżbieta Biardzka czuje się wygodnie. Część tego fragmentu opiera się na zreferowaniu założeń paktu komunikacyjnego Patricka Charaudeau, w którym to ujęciu są kwestie wymagające wyjaśnienia np. słuszność wyodrębnionych przez autora strategii odnoszonych do danych zewnętrznych paktu (czy strategia perswazyjna i strategia uwodziciela nie są w jakiejś mierze tożsame?). Rażą też drobiazgi - uproszczone wyjaśnienie, czym jest lead/lid (,krótkie redakcyjne streszczenie wiadomości” [Biardzka 2014: 47]) czy skrót myślowy o dwu gatunkach dziennikarskich („Tradycyjnie wyróżnia się dwa gatunki dziennikarskie: informacyjny i publicystyczny" [Biardzka 2014: 49]). Zupełnie nieprzystająco do całości prezentuje się też fragment o rodzajach i gatunkach, który jest oczywisty i zbyt oględny.

Zasadniczą część monografii zajmuje charakterystyka materiału prasowego, który - zgodnie z zaplanowanym trybem postępowania - staje się podstawą pracy analitycznej. Dwa kolejne rozdziały, 4 i 5, są bardzo rzetelnymi i dokładnymi opisami „morfologicznymi”, objaśniającymi funkcjonowanie cząstek składowych przytoczenia - mowy towarzyszącej i cytatu. Część czwarta poświęcona jest mowie towarzyszącej, a więc wszystkim tym składnikom zdarzenia słownego, które dotyczą jego elementów niewerbalnych. Te fragmenty mowy przytoczonej noszą w opracowaniach rozmaite nazwy komentarz sprawozdawcy (narratora), didaskalia (narracyjne/dziennikarskie), mowa atrybucyjna, akompaniament narracyjny, zdanie towarzyszace, zdanie wprowadzajace, wprowadzenie. Elżbieta Biardzka uwypukla znaczenie tych cząstek tekstu, gdyż poza wartością kompozycyjną mają one silne właściwości interpretacyjne - to od nich zależy sposób odczytania cytatu, to one działają niczym drogowskazy nakierowujące odbiorczą uwagę na pożądaną ścieżkę znaczeniową. 
Autorka uruchomiła aparat analityczny, który pozwolił jej na delimitację mowy towarzyszącej na zewnątrz sekwencji mowy przytoczonej i wewnątrz niej. Autorka odnotowuje wiele przykładów z mniej i bardziej skomplikowaną zawartością i wskazuje na rozmaite kryteria - składniowe, kompozycyjne, tematyczne, semantyczne - które mogą pomóc w ustalaniu granic omawianych zjawisk. Trafnie konstatuje: „Nie ma sensu szukać rodzaju zamkniętej, apriorycznej listy danych mowy towarzyszącej. Taki inwentarz byłby zawsze nieco arbitralny. [...] Proponuję przyjąć, że lista danych mowy towarzyszącej jest szeroka i otwarta..." [Biardzka 2014: 57-58]. A umieściła na niej Autorka: rozwiązania gramatyczne i tekstowe (zdania, równoważniki zdań, wyrażenia parentetyczne („nie-zdania”), konstrukcję „mieć + bezokolicznik”) oraz rozwiązania graficzne (myślnik, cudzysłów, nawiasy, przecinki, dwukropek). W obrębie ustaleń dotyczących mowy towarzyszącej wymieniona zostaje także jej tematyka, wiążąca się z trzema obszarami: cytowanymi nadawcami (nadawca cytatu, jak się zachowywał, jak mówił), przekazem słownym (ocena, streszczenie, wyjaśnienie, interpretacja treści cytatu), okolicznościami (parametry czasowo-przestrzenne, wydarzenia towarzyszące).

Ważną, prototypową cząstką mowy towarzyszącej są verba dicendi - stanowią jej jądro. Elżbieta Biardzka pogrupowała je tematycznie na podstawie ustaleń Ghassana Mourada i Jean-Pierre'a Desclésa, Michela Martins-Baltara, Wojciecha Górnego, Catherine Kerbrat-Orecchioni oraz Moniki Monville-Burston w sześć zestawów: czasowniki nadawczo-odbiorcze, emotywne, ewaluatywne, wyrażające postawy komunikacyjne, illokucyjne, parawerbalne. Czasowniki tejak zauważa Badaczka - mogą zostać zastąpione przez liczne funkcjonalne substytuty, jednak zawsze wskazują one zachowania słowne i są sygnałem cytatu.

I właśnie cytat i jego opis pojawiają się w studium jako kolejny zakres tematyczny - Autorka z dużą sprawnością wskazuje na cytaty dosłowne (bezpośrednie reprodukcje), przeformułowane (np. zredukowane) oraz mieszane. Co ważne, trafnie zauważa, że chociaż kształt cytatu decyduje o stopniu dokładności dziennikarskiej relacji, to przecież dziennikarz wybiera kształt dla cytowanych wypowiedzi. W zależności od strategii nadawczej, ale też przy uwzględnieniu wymagań gatunkowych nadaje on wypowiedzi cytowanej właściwą formę - od większych, wielozdaniowych partii tekstu (cytaty dosłowne całkowite), przez cytaty dosłowne cząstkowe (wysepki dosłowności), parafrazy (gdy wypowiedź pierwotna filtrowana jest przez dziennikarza) i kondensaty (najbardziej niedokładne, zagęszczone cytaty, mowa znarratywizowana), po formy cytatów mieszanych.

Naturalną koleją rzeczy po wieloaspektowym omówieniu składników mowy przytoczonej (mowy towarzyszącej i cytatu) następuje w monografii roz- 
dział poświęcony montażowi tych elementów pt. Typy kombinatoryki w mowie przytoczonej. Autorka wynotowuje w nim wiele kombinacji, w których zmianie ulegają pozycje względem siebie cząstek składowych mowy przytoczonej. Układają się one w dwa zasadnicze zręby - kombinatorykę wolną i zależną. Analiza materiału prasowego owocuje wyodrębnieniem kilku tendencji w realizacjach mowy przytoczonej, wśród których najbardziej wyraziste dotyczą dosłownego relacjonowania wypowiedzi, kumulacji rozmaitych sekwencji mowy przytoczonej oraz streszczeń cytowanych słów.

Sekwencje mowy przytoczonej funkcjonalizują się na trzech poziomach: fabularnym, kompozycyjnym oraz narracyjnym, w odniesieniu do skali lokalnej i globalnej. Konieczne jest też, co postuluje Autorka, uwzględnienie aspektu odbioru i odbiorcy. Wieńcząca całość analiza funkcji mowy przytoczonej przynosi ustalenia dotyczące ról mowy przytoczonej, które może ona pełnić w wymienionych obszarach. I tak omawia Elżbieta Biardzka funkcję sytuującą (nadawca, odbiorca, czas), amplifikującą (charakterystyka realizacji wokalnej), odnosi się do właściwości kompozycyjnych sekwencji mowy przytoczonej czy też punktów widzenia reprezentowanych przez postacie cytowane i przez dziennikarzy. Zresztą z analiz tych wyłania się obraz polskich dziennikarzy relacjonujących cudze słowa - są oni wszystkowiedzący, wszechobecni, umiarkowanie aktywni fabularnie, niezbyt rzetelnie oddzielający przytoczenia od opowiadania o zdarzeniach, zakotwiczeni w aktualności, nie są z kolei skłonni, by wykorzystywać cytaty dosłowne (i być może wynika to z ich małej sprawności retorycznej).

Studium Elżbiety Biardzkiej daje wnikliwy opis zróżnicowanych sekwencji mowy przytoczonej w polskiej prasie codziennej, wynikający z nastawienia dyskursywnego w podejściu badawczym. Autorka przeprowadza rzetelne, czasami nawet nazbyt drobiazgowe analizy, pokazując rozmaite praktyki cytowania stosowane przez dziennikarzy. Nie jest to jednak publikacja dla dziennikarzy przeznaczona, może ich zaskoczyć specjalistyczny język i hermetyczność przekazu, być może nawet medioznawca nie podoła wymaganiom tej lektury. Ta monografia jest kierowana do lingwistów, osób zawodowo parających się deskrypcją języka mediów, powinni po nią sięgnąć również ci wszyscy, którzy chcą od najlepszych uczyć się niełatwej sztuki analizowania materiału badawczego, adepci badań wychodzących poza opis strukturalny, uwzględniający kryteria semantyczne i/lub pragmatyczne. 